\title{
Pengaruh Solusi Daun Binahong (Anredera Cordifolia) Dalam Mempertahankan Kesehatan Mulut Ibu Hamil di Desa Karang Tengah Sukabumi Jawa Barat 2019
}

\author{
Andi Julia Rifiana*, Nova Putri Agustin, Anni Suciawati \\ Fakultas Ilmu Kesehatan, Universitas Nasional, Jakarta, Indonesia \\ Corresponding author: Andi Julia Rifiana (andi.rifiana@civitas.unas.ac.id) \\ Received: Mei, 16 2020; Accepted: June, 19 2020; Published: September, 12020
}

\begin{abstract}
ABSTRAK
Rata-rata populasi Indonesia dengan masalah gigi dan mulut adalah 25,9\% dan hanya 8,1\% yang mendapat perawatan. di Kota Sukabumi ada peningkatan sebesar 55\% untuk kasus karies gigi. Ini disebabkan oleh adanya mikroorganisme yang memfermentasi berbagai jenis karbohidrat menjadi asam. $\mathrm{pH}$ saliva adalah cairan kental yang diproduksi oleh kelenjar saliva. Daun binahong memiliki sifat kimia, yaitu saponin, alkaloid, polifenol dan triterpenoid. Untuk mengetahui pengaruh Larutan Daun Binahong dalam Menjaga Kesehatan Gigi dan Mulut pada Wanita Hamil di Desa Karang Tengah, Kabupaten Gunung Puyuh, Kota Sukabumi. Eksperimen semu dengan One Group Pretest-posttest Design. Desain ini adalah bahwa hanya ada satu kelompok subjek yang diamati tanpa kelompok pembanding, pengukuran dilakukan dua kali sebelum yaitu perlakuan yang diberikan dan setelah perlakuan yang diberikan. Sampel dalam penelitian ini berjumlah 32 orang. Teknik pengambilan sampel menggunakan total sampling. Tes yang berbeda menggunakan Tes Wilcoxon, sig. ( 2 ekor) $0,000(\alpha<0,05)$, yang merupakan perbedaan sebelum dan sesudah membilas larutan daun binahong. Uji efek menggunakan Mann Whitney dengan nilai 0,000 $(\alpha<0,05)$, yaitu pengaruh larutan daun binahong terhadap pH saliva pada ibu hamil di Desa Karang Tengah, Sukabumi. Ada efek larutan daun binahong pada $\mathrm{pH}$ saliva pada wanita hamil di Desa Karang Tengah, Sukabumi. Larutan daun binahong diharapkan menjadi salah satu terapi non-farmakologis yang dapat diterapkan untuk menjaga kesehatan mulut pada wanita hamil.
\end{abstract}

Kata Kunci: Daun Binahong, pH Saliva, Ibu Hamil

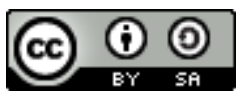

This is an open-acces article distributed under the terms of the Creative Commons Attribution-ShareAlike 4.0 International License.

\section{PENDAHULUAN}

Penelitian Riskesdas (2018), menunjukkan bahwa proporsi masalah gigi dan mulut di Indonesia adalah sebesar 57,6\%. Research Riskesda (2013) menunjukkan bahwa rata-rata pravalensi penduduk Indonesia dengan masalah gigi dan mulut adalah $25,9 \%$. Data penelitian tentang jumlah layanan gigi dan mulut di provinsi Jawa Barat pada tahun 2018, yaitu karies gigi di Jawa Barat menduduki peringkat keenam dari penyakit yang dikeluhkan oleh masyarakat, prevalensi karies di Jawa Barat adalah 79,7\% (WHO, 2019). Prevalensi gingivitis pada kehamilan telah dilaporkan berkisar antara 30 hingga $100 \%$ wanita yang sedang hamil. 
Prevalensi sesuai dengan prevalensi di Indonesia bahwa persentase penduduk Indonesia yang mengalami masalah kesehatan gigi dan mulut berdasarkan Riskesdas 2018 adalah 30,9\%.

\section{METODE}

Jenis penelitian ini adalah penelitian Quasi Eksperimen dengan One Group Pretestposttest Design. Populasi dalam penelitian ini adalah semua wanita hamil di desa Karang Tengah, Kecamatan Gunung Puyuh Sukabumi, Jawa Barat 2019. Berdasarkan data dari wanita hamil dari Puskesmas Karang Tengah pada Oktober 2019 di daerah Desa Karang Tengah berdasarkan PWS, ada adalah 32 wanita hamil.

Teknik pengambilan sampel dalam penelitian ini menggunakan total sampling dimana semua sampel diambil sehingga penelitian ini adalah penelitian populasi.

Instrumen penelitian yang digunakan dalam penelitian ini adalah indikator $\mathrm{pH}$ yang merupakan senyawa halokromik yang ditambahkan dalam jumlah kecil ke sampel, umumnya larutan yang akan memberi warna sesuai dengan kondisi $\mathrm{pH}$ larutan. Pada suhu $25^{\circ}$ Celcius, nilai $\mathrm{pH}$ untuk larutan netral adalah 7,0 Jenis penelitian ini adalah penelitian Quasi Eksperimen dengan One Group Pretest-posttest Design. Populasi dalam penelitian ini adalah semua wanita hamil di desa Karang Tengah, Kecamatan Gunung Puyuh Sukabumi, Jawa Barat 2019. Berdasarkan data dari wanita hamil dari Puskesmas Karang Tengah pada Oktober 2019 di daerah Desa Karang Tengah berdasarkan PWS, ada adalah 32 wanita hamil.

Teknik pengambilan sampel dalam penelitian ini menggunakan total sampling dimana semua sampel diambil sehingga penelitian ini adalah penelitian populasi.

Instrumen penelitian yang digunakan dalam penelitian ini adalah indikator $\mathrm{pH}$ yang merupakan senyawa halokromik yang ditambahkan dalam jumlah kecil ke sampel, umumnya larutan yang akan memberi warna sesuai dengan kondisi $\mathrm{pH}$ larutan. Pada suhu $25^{\circ}$ Celcius, nilai $\mathrm{pH}$ untuk larutan netral adalah 7,0.

\section{HASIL}

\section{A. Analisi Univariat}

Distribusi Frekuensi saliva pH ibu hamil sebelum berkumur Solusi Daun Binahong dalam Menjaga Kesehatan Gigi dan Mulut Wanita Hamil Desa Karang Tengah Desa Sukabumi Jawa Barat 2019

\begin{tabular}{cccccccc}
\hline \multirow{2}{*}{$\mathbf{N}$} & & \multicolumn{9}{c}{ pH Saliva } & \multirow{2}{*}{ Mean } & Katagori \\
\cline { 3 - 6 } & Day & Asam & $(\boldsymbol{\%})$ & Basa & $(\boldsymbol{\%})$ & & \\
\hline 32 & 1 & 32 & 100 & 0 & 0 & 5,75 & Acid \\
& 2 & 32 & 100 & 0 & 0 & 5,8438 & Acid \\
& 32 & 100 & 0 & 0 & 5,8125 & Acid \\
& 3 & 32 & 100 & 0 & 0 & 5,9062 & Acid \\
& 5 & 32 & 100 & 0 & 0 & 5,9062 & Acid \\
6 & 32 & 100 & 0 & 0 & 5,9062 & Acid \\
& 7 & 32 & 100 & 0 & 0 & 5,9375 & Acid \\
\hline
\end{tabular}

Tabel di atas menunjukkan bahwa semua $\mathrm{pH}$ saliva wanita hamil sebelum membilas larutan daun binahong dari hari 1-7 bersifat asam dengan rata-rata pada hari 1 (5.9688), hari 2 (5.8438), hari $3(5,8125)$, hari 4 -6 (5.9062), dan hari ke 7 (5.9375). 
Distribusi Frekuensi pH Saliva Wanita Hamil Setelah Berkumur Solusi Daun Binahong dalam Menjaga Kesehatan Gigi dan Mulut Wanita Hamil Desa Karang Tengah, Sukabumi, Jawa Barat 2019

\begin{tabular}{|c|c|c|c|c|c|c|c|}
\hline \multirow{2}{*}{$\mathbf{N}$} & \multirow{2}{*}{ Day } & \multicolumn{4}{|c|}{ pH Saliva } & \multirow{2}{*}{ Mean } & \multirow{2}{*}{ Kategori } \\
\hline & & Asam & $(\%)$ & Basa & $(\%)$ & & \\
\hline \multirow[t]{7}{*}{32} & 1 & 3 & 9,4 & 29 & 90,6 & 7 & Neutral \\
\hline & 2 & 2 & 6,2 & 30 & 93,8 & 7,0312 & Basa \\
\hline & 3 & 1 & 3,1 & 31 & 96,9 & 7,0938 & Basa \\
\hline & 4 & 1 & 3,1 & 32 & 96,9 & 7,0625 & Basa \\
\hline & 5 & 1 & 3,1 & 32 & 96,9 & 7,0312 & Basa \\
\hline & 6 & 0 & 0 & 32 & 100 & 7,0625 & Basa \\
\hline & 7 & 0 & 0 & 32 & 100 & 7,1562 & Basa \\
\hline
\end{tabular}

Tabel di atas menunjukkan bahwa $\mathrm{pH}$ rata-rata saliva ibu hamil setelah membilas larutan daun binahong pada hari 1 menunjukkan bahwa $\mathrm{pH}$ saliva netral dan hari 2-7 bersifat basa, dengan hasil rata-rata hari 1-7, yaitu pada hari 1 (7), hari 2 (7.0312), hari 3 (7.0938), hari 4 (7.0625), hari 5 (7.0312), hari 6 (7.0625), dan hari ke 7 (7.1562).

\section{B. Analisis Bivariat}

Perbedaan pH Saliva pada Wanita Hamil sebelum dan sesudah membilas Larutan Daun Binahong di Desa Karang Tengah, Sukabumi, Jawa Barat 2019

\begin{tabular}{lr}
\hline \multicolumn{2}{c}{ Wilcoxon } \\
\hline & \multicolumn{2}{c}{ sebelum- } \\
& sesudah \\
\hline Z & $-5,568$ \\
Asymp.Sig.(2-tailed) & 0,000 \\
\hline
\end{tabular}

Tabel di atas menunjukkan bahwa hasil skor sebelum dan sesudah membilas larutan daun binahong pada hari 1-7 sig $(0,000)$ sehingga $(\alpha<0,05)$ terdapat perbedaan sebelum dan sesudah membilas larutan daun binahong dalam menjaga kesehatan gigi dan mulut. pada wanita hamil.

Pengaruh Larutan Daun Binahong pada pH Saliva Wanita Hamil dalam Menjaga Kesehatan Gigi dan Mulut Wanita Hamil Desa Karang Tengah, Sukabumi, Jawa Barat 2019

\begin{tabular}{lr}
\hline & $\begin{array}{c}\text { Effect of } \\
\text { solution }\end{array}$ \\
\hline Mann- & 0,000 \\
Whitney U & 528,000 \\
Wilcoxon W & $-7,937$ \\
Z & 0,000 \\
Asymp. Sig. & \\
(2-tailed) & \\
\hline
\end{tabular}

Tabel di atas menunjukkan bahwa hasil skor sebelum dan sesudah berkumur larutan daun binahong pada hari 1-7 ada nilai pada Mann-Whitney $(, 000)$ sehingga $(\alpha<0,05)$ terdapat pengaruh larutan daun binahong dalam menjaga oral. kesehatan pada ibu hamil 


\section{PEMBAHASAN}

\section{Rata-rata pH Saliva sebelum dan sesudah membilas larutan daun binahong}

Selama kehamilan ada perubahan fisiologis yang mengakibatkan penurunan $\mathrm{pH}$ saliva dan pada trimester pertama (0-3 bulan kehamilan) wanita hamil biasanya akan merasa lesu, mual dan kadang muntah. Lambat, mual dan muntah dapat menyebabkan peningkatan suasana asam di mulut (Depkes, 2012).

Tingkat keasaman $(\mathrm{pH})$ saliva merupakan faktor penting yang berperan dalam rongga mulut, sehingga saliva dapat berfungsi dengan baik, komposisi saliva dan sifat saliva harus dijaga dalam keseimbangan optimal, terutama tingkat keasaman. Karena $\mathrm{pH}$ sangat terkait dengan beberapa aktivitas pengunyahan yang terjadi di rongga mulut. Penurunan $\mathrm{pH}$ saliva dapat menyebabkan demineralisasi yang cepat pada elemen-elemen gigi, sedangkan peningkatan $\mathrm{pH}$ dapat membentuk kolonisasi bakteri yang juga meningkatkan pembentukan kalkulus. PH saliva normal berkisar 6,8 -7. Sedangkan $\mathrm{pH}$ krisis saliva adalah 5,5. Mengukur $\mathrm{pH}$ saliva, $\mathrm{pH}$ meter atau kertas lakmus dapat digunakan dengan indikator $\mathrm{pH}$. Anda melakukan ini dengan merendam lakmus selama 10 detik. Kemudian cocokkan warna yang terbentuk menggunakan indikator $\mathrm{pH}$. Hasil yang diperoleh berupa merah (asam) dan hijau (basa). (Rahayu \& Kurniawati, 2018).

Menurut penelitian sebelumnya Habib, Wihardja \& Kintawati (2019) keasaman saliva $(\mathrm{pH})$ adalah salah satu faktor penting yang dapat mempengaruhi proses demineralisasi pada permukaan gigi. Perubahan $\mathrm{pH}$ saliva dipengaruhi oleh pengaturan kuantitatif dan kualitatif dari elektrolit dan kapasitas buffer dalam saliva. Dalam keadaan normal, $\mathrm{pH}$ saliva berkisar 6,8-7,2. Karbohidrat yang tersisa di rongga mulut akan difermentasi oleh bakteri patogen oral seperti Streptococcus mutans untuk menghasilkan asam yang akan mengurangi $\mathrm{pH}$ saliva.

Penelitian Karnik (2015) menyatakan bahwa penurunan $\mathrm{pH}$ saliva pada wanita hamil dapat disebabkan oleh berbagai faktor, termasuk peningkatan kadar hormon progesteron yang menyebabkan penurunan konsentrasi ion bikarbonat (HCO3-), peningkatan Enzim amilase, mual dan muntah, dan seringkali wanita hamil mengkonsumsi makanan manis atau asam. PH saliva wanita hamil di bawah $\mathrm{pH}$ saliva normal, sedangkan $\mathrm{pH}$ saliva wanita tidak hamil berada dalam batas normal, tetapi kedua kelompok memiliki $\mathrm{pH}$ saliva di atas $\mathrm{pH}$ kritis $(5,5)$.

\section{Perbedaan sebelum dan sesudah membilas larutan daun binahong pada pH saliva pada ibu hamil}

Dalam penelitian ini tes analisis bivariat untuk menentukan tes yang berbeda menggunakan uji Wilcoxon karena hasil data uji normalitas menggunakan uji Shapiro Willk diperoleh nilai signifikansi untuk data sebelum dan setelah membilas larutan daun binahong $(0,000)$. Karena distribusinya tidak normal $(\alpha<0,05)$, maka uji alternatif yang digunakan adalah uji Wilcoxon. Tabel 4.6 menunjukkan Asymp.Sig (2 tailed), yaitu $(0,000)$ berarti $\alpha=0,000$ $<0,01$ maka ada perbedaan dalam saliva ph ibu hamil sebelum dan sesudah diberikan larutan daun binahong.

Penelitian ini sama dengan Istiqomah (2015), pH saliva sebelum membilas daun binahong sebagian besar memiliki $\mathrm{pH}$ saliva asam dan setelah membilas sebagian besar memiliki pH alkali. Hal ini dimungkinkan karena $\mathrm{pH}$ saliva dengan kriteria basa disebabkan oleh rasa pahit yang terdapat pada daun binahong yang dapat merangsang kecepatan sekresi, sehingga mempengaruhi derajat asam $(\mathrm{pH})$ dalam mulut, karena sistem buffer dapat menjaga $\mathrm{pH}$ saliva tetap konstan. Perubahan $\mathrm{pH}$ saliva yang terjadi antara sebelum dan sesudah berkumur larutan daun binahong disebabkan oleh berbagai faktor dalam rongga mulut yang dapat mempengaruhi $\mathrm{pH}$ saliva. Kecepatan sekresi saliva langsung mempengaruhi derajat asam $(\mathrm{pH})$ dalam mulut, kecepatan sekresi dipengaruhi oleh rangsangan seperti asam, manis, pahit 
dan pedas Amerongen (1991). Stimulasi dalam bentuk pahit dapat merangsang sekresi saliva dalam jumlah tinggi, menyebabkan saliva menjadi lebih tipis (viskositas saliva lebih rendah). Saat aliran saliva meningkat, nilai $\mathrm{pH}$ juga meningkat. Kapasitas buffer saliva merupakan faktor penting yang berperan dalam menjaga $\mathrm{pH}$ saliva. Kapasitas buffer saliva dan $\mathrm{pH}$ saliva meningkat dengan laju sekresi. Produk saliva dapat dirangsang oleh rangsangan kimia, yaitu membilas daun Binahong yang menyebabkan peningkatan $\mathrm{pH}$ saliva ke arah pangkalan. $\mathrm{PH}$ saliva dasar menyebabkan pengendapan mineral yang disebut kalkulus. Aliran saliva meningkat ketika saliva distimulasi dengan rasa pahit yang berasal dari daun binahong. Rasa pahit disebabkan oleh daun binahong yang memiliki kandungan kimia, yaitu saponin, alkaloid, polifenol dan triterpenoid

\section{Efek larutan daun binahong pada pH saliva pada wanita hamil}

Dalam penelitian ini uji analisis bivariat untuk mengetahui pengaruh uji menggunakan uji Mann Whitney karena dari hasil data uji normalitas menggunakan uji Shapiro Willk diperoleh nilai signifikansi untuk data sebelum dan sesudah membilas larutan daun binahong $(0,000)$. Karena distribusinya tidak normal $(\alpha<0,05)$, maka tes alternatif yang digunakan adalah tes Mann Whitney. Tabel 4.7 hasil menunjukkan Asymp.Sig ( 2 tailed), yaitu $(0,000)$ yang berarti $\alpha=0,000<0,01$ maka hipotesis penelitian diterima yang berarti ada pengaruh larutan daun binahong pada $\mathrm{pH}$ saliva pada wanita hamil.

Faktor-faktor untuk perubahan dalam sistem pencernaan, sistem pencernaan dipengaruhi dalam beberapa cara karena kehamilan. Dan menurut penelitian sebelumnya oleh Ratnasari (2015) terjadi peningkatan estrogen dan progesteron horrmon yang dapat mengganggu keseimbangan cairan tubuh, meningkatkan sirkulasi darah, dan memperlambat kontraksi otototot saluran pencernaan. Menyebabkan sekresi saliva menjadi lebih asam. Serta regurgitasi terjadi sehingga mulut terasa masam. Tingkat keasaman dan kapasitas penyangga disebabkan oleh pengaturan bikarbonat, yang meningkat dengan kecepatan sekresi. Ini dapat diartikan bahwa $\mathrm{pH}$ dan kapasitas buffer saliva meningkat dengan meningkatnya laju sekresi saliva. Bagian lain dari saliva, seperti fosfat (terutama HPO42) dan protein, hanyalah tambahan sekunder untuk kapasitas penyangga. Ureum dalam saliva dapat digunakan oleh mikroorganisme di rongga mulut dan menghasilkan pembentukan amonia. Amonia akan menetralisir hasil akhir metabolisme asam bakteri, sehingga $\mathrm{pH}$ menjadi lebih tinggi. (Nurhaeni, 2019).

Keasaman $(\mathrm{pH})$ saliva adalah salah satu faktor penting yang dapat mempengaruhi proses demineralisasi pada permukaan gigi. Perubahan $\mathrm{pH}$ saliva dipengaruhi oleh pengaturan kuantitatif dan kualitatif dari elektrolit dan kapasitas buffer dalam saliva. Dalam keadaan normal, $\mathrm{pH}$ saliva berkisar 6,8-7,2. Karbohidrat yang tersisa di rongga mulut akan difermentasi oleh bakteri patogen oral seperti Streptococcus mutans untuk menghasilkan asam yang akan mengurangi $\mathrm{pH}$ saliva.

Penelitian ini sama dengan hasil penelitian yang dilakukan oleh Danan et al (2019) yang menunjukkan pengaruh pembilasan larutan daun binahong dengan pembilasan daun yang lebih banyak dengan kriteria $\mathrm{pH}$ asam asam binahong, setelah dibilas dengan daun binahong $\mathrm{pH}$ saliva menuju pangkalan. Peningkatan $\mathrm{pH}$ saliva setelah dibilas dapat menetralkan keadaan asam yang memicu karies gigi.

Asumsi penelitian adalah larutan kumur binahong adalah salah satu intervensi untuk menjaga kesehatan mulut ibu hamil. Makanan yang kita konsumsi setiap hari dapat mempengaruhi perubahan $\mathrm{pH}$ saliva di rongga mulut, terutama makanan yang bersifat asam akan cenderung menyebabkan perubahan $\mathrm{pH}$ saliva turun dan menjadi asam juga. Selain itu, hasil metabolisme karbohidrat oleh mikroorganisme di rongga mulut juga akan menghasilkan asam yang akan memicu proses demineralisasi enamel dan dentin, yang akan menyebabkan 
karies. Produksi asam dari mikroorganisme dalam plak gigi akan berlanjut selama proses metabolisme karbohidrat. Kurva Stephan menunjukkan penurunan tajam keasaman plak gigi setelah konsumsi karbohidrat. Bakteri plak akan memfermentasi karbohidrat (terutama gula dan pati) dan akan menghasilkan asam, ion $\mathrm{H}$ dalam asam akan menggantikan ikatan Ca dalam hidroksi apatit dalam enamel. Larutan berkumur binahong membantu meningkatkan $\mathrm{pH}$ saliva dalam menjaga kesehatan mulut ibu hamil. Stimulus pahit yang ditemukan pada daun binahong dapat merangsang sekresi saliva dalam jumlah tinggi, menyebabkan saliva menjadi lebih tipis (viskositas saliva lebih rendah). Saat aliran saliva meningkat, nilai $\mathrm{pH}$ juga meningkat. Dengan membilas larutan daun binahong, diharapkan hasil akhirnya akan ditingkatkan untuk menjaga kesehatan mulut ibu hamil.

\section{KESIMPULAN}

Ada efek membilas mulut dengan larutan daun binahong pada $\mathrm{pH}$ saliva ibu hamil yaitu sebelum membilas larutan daun binahong semua wanita hamil memiliki $\mathrm{pH}$ saliva asam dan setelah membilas larutan daun binahong $\mathrm{pH}$ rata-rata saliva pada wanita hamil adalah basa.

\section{UCAPAN TERIMAKASIH}

Ucapan terima kasih disampaikan kepada Universitas Nasional yang telah memberikan dukungan dan memberikan peluang bagi penulis untuk melakukan penelitian ini, ucapan terima kasih juga disampaikan kepada Fakultas Ilmu Kesehatan yang selalu mendorong untuk selalu bekerja, juga untuk keluarga, teman yang telah mendukung keduanya secara moral dan material.

\section{DAFTAR PUSTAKA}

Amerongen, Nieuw A. (1991). Ludah dan Kelenjar Ludah Arti Bagi Kesehatan Gigi. Yogyakarta: Gadjah Mada University Press, 18-23, 37-38.

Arumugham K. (2019). Gambaran Status Kebersihan Rongga Mulut. Universitas Sumatera Utara, i.

Danan, Habibah S.S \& Rahmawati H. I. (2019). Pengaruh Kumur-Kumur Larutan Daun Binahong (Adredera Cordofolia Ten Stennis) terhadap penyembuhan Gingivitis pada siswa SMP 13 Cempaka Banjarbaru. Jurnal Skala Kesehatan Politeknik Kesehatan BanjarmasinVol.10, No.2, Juli 2019E-ISSN: 2615 -2126, P-ISSN: 2087 -152X, 92.

Dinkes. (2017). Profil Kesehatan DInas Kesehatan Provinsi Jawa Barat 2017. Retrieved from www.diskes.jabarprov.go.id

(2019). Dinas Kesehatan Jawa Barat. Retrieved from data jabar prov: https://data.jabarprov.go.id/dataset/jumlah-pelayanan-gigi-danmulut/resource/fc98d277-1169-440d-a685-0062f670b1ee

Habib I.S, Wihardja, R., \& Kintawati, S. (2019). Perbedaan pH saliva antara wanita hamil dan tidak hamil. J Ked Gi Unpad. April 2019; 31(1): 37-42., 38.

Istiqomah, N., \& Santoso, B. (2015). Pengaruh Berkumur Larutan Daun Binahong terhadap pH Saliba pada Ibu Hamil Desa Babadan Kabupaten Semarang. JURNAL KEBIDANAN Vol.4 No. 9. Oktober 2015 ISSN .2089-7669, 31.

Karnik AA, Pagare SS, Krishnamurthy V, et al (2015). Determination of salivary flow rate, $\mathrm{pH}$, and dental caries during pregnancy: A study. J Indian Acad Oral Med Radiol. 2015;27(3):372-6 DOI: 10.4103/09721363.170454

Kesehatan, D. J. (2012). Pedoman pemeliharaan kesehatan gigi dan mulut ibu hamil dan anak usia balita bagi tenaga kesehatan di fasilitas pelayanan kesehatan. Jakarta: Kementerian Kesehatan Republik Indonesia, 5-11. 
Rahayu, Y. C., \& Kurniawati, A. (2018). CAIRAN RONGGA MULUT. Yogyakarta : Pustaka Panasea.

Ratnasari, D. M. (2015). Pengaruh Larutan Kumur Probiotik Terhadap Peningkatan pH Saliva. xiii.

Nurhaeni, H. (2019). Pengaruh Berkumur Larutan Daun Binahong (Anredera Cordifolia) terhadap pH Saliva pada Ibu Hamil di Desa Pabentengan Kecamatan Marusu Kabupaten Maros. Vol. 18 No. 1 Tahun 2019, 48. 